\title{
The Effect of Balanced Scorecard as a Strategic Implementation Tool to Enhance Efficiency at Kenya Bureau of Standards
}

\author{
Listone Kipkirui Langat $^{1}$, \& Dr. Daniel M. Wanyoike ${ }^{2}$ \\ ${ }^{I}$ The Corresponding Author is a Master of Business Administration (Strategic Management) student at Jomo \\ Kenyatta University of Agriculture and Technology, Nakuru Campus, Kenya. \\ ${ }^{2}$ senior lecturer at Jomo Kenyatta University of Agriculture and Technology, Nakuru Campus, Kenya.Jomo \\ Kenyatta University of Agriculture and Technology
}

\begin{abstract}
The Government of Kenya has made substantial investment in the public sector through creation of diverse corporations. However, most public sector firms have not shown the required levels of efficiency and effectiveness that would be required of them. This has necessitated diverse measures such as the Results Based Management System (RBMS) which was initiated by the Government of Kenya in 2005. This management system has been put in place to ensure efficiency and effectiveness in service delivery in public sector organizations. Therefore the Kenya Bureau of Standards (KEBS), like any other public sector organizations, is required to operate under the RBMS of which Performance Contracts $(P C)$ are a key component. The application of the Balanced Score Card (BSC) in the strategy management process has been found to be a useful tool in the clarification of the vision and mission of organizations and the rallying of the organizational members towards its achievement. This study examined the role of the BSC as a strategic implementation tool to enhance efficiency at KEBS. The specific research objectives included the examination of financial perspective, customer perspective, internal business processes perspective, and learning and growth perspective of the BSC on the efficiency at KEBS. The theoretical underpinning of the study was open systems theory and the institutions' theory. The study was based on the descriptive research design with the target population of 150 management staff at KEBS. The sample size is 109 respondents. The study out the following; that there was a significant relationship between financial perspective of the balanced scorecard and organizational efficiency at KEBS. This was attributed to the availability and sufficiency of resources at both the organizational and departmental levels for KEBS to execute its mandates at those levels on time, and in the required scope hence improving on the organizational efficiency. Secondly, there was a significant relationship between the customer perspective aspect of the BSC and organizational efficiency at KEBS. The customer perspective was important to the organizational efficiency at KEBS through reduction of turnaround timelines in service delivery. There was also a significant relationship between the internal business process perspective of the BSC and organizational efficiency at KEBS. This was attributed to the internal business processes ability to influence customer satisfaction. Lastly, there was a significant and positive relationship between learning and growth perspective aspect of the BSC and organizational efficiency at the organization. This significance was attributed to the ability of KEBS to benchmark and learn on best practices on diverse aspects of its mandates. The study recommends that KEBS should focus on the learning and growth perspective of the balanced scorecard as it had the greatest influence on its organizational efficiency. The study suggests further studies on the examination on other financial perspective metrics of the balanced scorecard and the ways in which it can help in organizational efficiency at KEBS.
\end{abstract}

Keywords: Balanced Scorecard, Customer Perspective, Financial Perspective, Internal Business Perspective, Learning \& Growth Perspective

\section{Introduction}

Governments have demanded greater transparency and accountability in regard to the use of public funds. Therefore, public sector organizations have turned to private sector performance management practices as potential means of improving and demonstrating their own performance and accountability (Amboga, 2009). In particular, there has been a move towards specifying strategic goals, which then form the basis for setting published performance targets against which public sector organizations must report (Wanyutu, 2014). Balance scorecard is widely advocated as having the potential to support these performance management. In particular, the BSC is thought to present a multi-dimensional view of performance across different objectives and stakeholders, as is required for many public sector organizations (Waruiru, 2009). Further, the BSC's focus on Key Performance Indicators (KPIs) that directs managerial attention to important drivers of organizational results, and informs performance management by linking these KPIs in causal relationships with desired outcomes (Momanyi, 2012). Despite this apparent match between the BSC and public sector performance 
management goals, very few studies to examine the issues and challenges that exist in public sector BSC implementation have been done.

Locally, several studies have been done on the application of BSC in both private and public sectors. Mugo (2014) examined the application of the BSC tool in strategy management implementation at Flashcom and concluded that Flashcom primarily made use of the BSC as a strategy implementation and performance management tool. On the other hand, Oketch (2015) sought to establish the application of the BSC in strategy implementation by the Kenya Commercial Bank and concluded that the Bank had applied the BSC in strategy implementation and performance management. Momanyi (2012) examined the extent to which Kenya Private Sector Alliance (KEPSA) had employed the BSC in implementation of its strategy. The study observed that KEPSA does indeed use the four perspectives of BSC in the development of its work plans. Nzuve \& Nyaega (2013) examined the application of the BSC in Performance Measurement at Essar Telkom Kenya. The study showed that the implementation of the BSC at Essar Telkom Kenya was successful up to a certain extent. Mureithi (2014) examined the application of BSC as a strategy management process tool by Kenya Petroleum Refineries Limited and found out that the BSC has enabled the company to link corporate strategy with KPIs at the departmental, and employee level, and communicate them across the company and has revolutionized the staff appraisal system. Some of the challenges faced includes: inadequate training on the BSC, lack of sustained effort to remind employees on its importance. Ochieng (2012) examined the strategic management practices at Kenya Bureau of Standards and concluded that KEBS has adopted a planning mode of strategy formulation and has documented its vision and mission statements. Secondly, KEBS's strategic stance and actions are greatly influenced by the regulatory frameworks and policies put in place by the government (Ochieng, 2012). The regulatory instruments such as performance contracting which the Kenya government introduced were found to be instrumental in strategy evaluation at KEBS. Therefore, Ochieng (2012) recommeded that KEBS should consider using other tool such as BSC for effective implementation and evaluation of its strategic plan.

Kenya Bureau of Standards (KEBS) is a state corporation established in 1974 through an Act of parliament, the Standards Act Cap 496 Laws of Kenya, to promote standardization in commerce and industry, to provide testing and calibration facilities, to assist in the implementation and practical application of standards and to maintain and disseminate International System of units (SI)(Ochieng, 2012). It is also mandated to undertake educational work in standardization and control the use of standardization marks and distinct marks. The KEBS has 15 departments namely: Standards development, Quality assurance and Inspection, Quality processes, Certification body, legal, ICT, Internal audit, Customer communication, National quality institute, Metrology, Testing, Market surveillance, Finance, Human resource and Procurement with a work force of 900 employees.

\section{Theoretical Review}

\section{Literature Review}

The study used the open systems theory and institutional theory. The open system theory was developed by the biologist Ludwig Von Bertalanffy (Kebu, 2015). The system is defined as a set of objects or entities that interrelate with one another to form a whole (Oketch, 2015). The system theory is concerned with the problems or relationships, of structures, and of inter-dependence, rather than with the constant attributes of object (Kebu, 2015). The systems theory views an organization as a social system consisting of individuals who cooperate within a formal framework, drawing resources, people, finance from their environment and putting back into that environment the products they produce or the services they offer (Oketch, 2015). The Open systems theory is concerned with understanding organizations in their entirety: therefore it takes a holistic rather than a particularistic approach thus reflected on its approach to change (Kebu, 2015).

The corner stone of the open systems theory is that the organizations are influenced by the environment in which they operate in. These organizational interactions occur through the use of the environment for provision of inputs and the release of outputs that is products and services to the environment (Oketch, 2015). Therefore, the organizations must consider the environment in their operations to ensure efficiency and success in their operations. This theory is applicable in this study because the BSC is concerned with the driving of future direction, building in cause and effect linkages while simultaneously taking into account both financial and intangible resources that can determine success or failure. The theory is also relevant because one of the BSC components is the customer which refers to a component within the organization's environment in which the organization must cater for to enable its efficiency in service provision.

On the other hand, the institutional theory was advanced by Selznick in 1957. The institutional theory is concerned on the transformation of organizations into institutions, focusing on routines, roles, beliefs and processes by which value is infused (Oketch, 2015). The institutional theory considers the processes by which structures, including ethics; rules, norms, and routines, become established as authoritative guidelines for social behavior which is an important aspect in change management. This change management is critical to enable the organizational efficiency as the organization keep on adjusting to arising issues. 


\section{Influence of Financial Perspective of the Balance Scorecard on Efficiency}

Although the BSC was developed in part as a reaction against the excessive reliance on financial measures, the financial measures are still an important component of the BSC (Nathan, 2015). According to Kinya (2012), measures in the Financial Perspective indicate whether the implementation of the company strategy and its execution are contributing to the improvement of the bottom-line results. Focusing resources, energy, and capabilities on customer satisfaction, quality, knowledge, and other factors in the other perspectives without incorporating indicators showing the financial returns of an organization may produce little added value (Thuo, 2012). According to Gitachu (2012), the Financial Perspective focuses on measures which have the goal of enhancing shareholder value. The most commonly used measures are derived from the objectives of revenue growth and productivity, such as return on equity, return on investment, revenue, gross margin, and other indicators (Nyaega, 2012).

Organizations' formulate and implement strategies from the perspective of financial plans, income and profit growth analysis and financial forecasts (Kebu, 2015). The financial performance perspective of the BSC addresses the question of how shareholders view the firm and which financial goals are desired from the shareholder's perspective. These measures include: Revenue growth, profit ratio, return on investment, utilization of allocated resources and cost reduction. Gichana, (2012) argue that financial performance measures indicate whether the company's strategy, its development, implementation and execution are contributing to the bottom line business improvement.

Financial perspective considers profitability and return on shareholder value. Measures such as return on investment and economic value added can be improved by increasing sales revenue, ensuring provision of quality goods and services, decreasing operating costs, enhancing asset utilization, and improving customer satisfaction and higher operating efficiency (Elesani, 2012). Currently, business environment is characterized by fast dynamic change in customers, competitors, technologies, suppliers, and regulators. Therefore, all organizations need to continuously scan the environment and be more innovative in order to survive (Amboga, 2009). Cost management focuses mainly on the firm's strategic positioning, the full set of cost drivers for the firm and its overall value chain (Kibuchi, 2015).

Gitonga (2014) suggested that cost management is a management accounting technique for planning and control in any organization's operation and production costs which is one of management control systems (MCS) for improved firm success.

Most government and non-profit organizations experience difficulties in using the original structure of the BSC, which places the financial perspective at the top of the hierarchy (Omollo, 2015). Since profitability or market share is not the primary objective for most governmental organizations, the structural framework of the BSC can be rearranged to place satisfaction of customers of these organizations or the goodwill of the constituents at the top of the hierarchy (Onyango, 2014). According to Elesani (2012) exclusive reliance on financial measures in a management system is incomprehensive, as financial measures are lag indicators that report on the outcomes from past actions. Exclusive reliance on financial indicators could promote behaviour that sacrifices long-term value creation for short-term performance thus negatively impacting on the organization's future sustainability (Amboga, 2009).

\section{Influence of Customer Perspective of the Balance Scorecard on Efficiency}

Customer perspective focuses on the analysis of different types of customers, their degree of satisfaction and the processes used to deliver products and services to customers (Kiragu, 2012). Measures include: Customer satisfaction index, number of complaints, service delivery timelines and response time (Nyangayo, 2014). It provides added value for the customer in the areas of price, quality, availability, accessibility, service, partnership, and reputation in order to support the core outcomes of customer acquisition, customer satisfaction and customer retention (Kibuchi, 2015).

Gitachu (2012) suggests that management should analyze how the customers view the company by measuring lead times, quality, performance and service, and costs. Management should also determine what the company must excel in. This may include the operation and production processes and competencies that are most critical such as cycle time, quality, employee skills, and productivity (Thuo, 2012). The company must also analyze the ability of the company to enhance its performance in ensuring customer satisfaction through launch of new customized and quality products, continuous improvements, creation of value and improve operating efficiencies (Wanyutu, 2014).

Customer focus has a direct impact on the financial performance of a firm especially on profitability and return on investment(ROI) through market expansion, increased market share and improved profitability (Nyaega, 2012). It also enhances organizational performance since it promotes customer loyalty (Momanyi, 2012). In the past, organization's focused mainly on meeting financial perspective however, due to the dynamic changes in the economic environment; they have discovered that financial performance depends upon customer's satisfaction or lack of it (Kinya, 2012). Customer satisfaction is a result of efficiency, turnaround 
time, quality of the organizations' processes and operations. The ability of the company to accomplish these processes depends on the operational capacity, human power quality, incentives given, and nature of management and information systems in place (Wekesa, 2015). Recently, businesses have introduced a system for improving their responsibility to the customers in terms of job improvement review (Kagunyi, 2014). For example, small quantity batch production increases cost but improve efficiency of management. Companies have introduced the BSC to evaluate their management and employee job performance based on its specific parameters as part of improvement in its overall performance (Momanyi, 2012).

A company should measure its performance through the view point of customers' eye to eliminate biasness in evaluation (Thuo, 2012). To put the BSC to work in rating performance, companies should articulate goals for time management, turnaround time, provision of quality goods and service and then translate them to achievable targets (Kariuki, 2012). Customer based measures are important and they must be translated into parameters of what the company must do internally to meet and exceed its customers' expectations (Kebu, 2015). Excellent customer performance is derived from quality and strategic processes, decisions and actions occurring throughout an organization (Gichana, 2012).

Customer perspective aims at individualizing objectives and measures to control the level of customer satisfaction through numerous rating indices, like the rate of acquisition of new customers, the market share of the chosen segment and customer retention (Kinya, 2012). If customers are not satisfied, they will find other suppliers that are more sensitive to their needs and desires (Thuo, 2012). Poor performance in customer focus is a leading indicator of future decline in growth and sustainability of the organization, even though the current financial picture may look good as it will eventually lead to decrease in market share as the customers move to where they feel they will get better services (Wanyutu, 2014).

\section{Influence of internal business process perspective of the balance scorecard on efficiency}

Great customer performance is the result of processes, decisions, and actions which managers need to focus on in order to satisfy customer needs (Gitachu, 2012). According to Nathan (2015), in the Internal Process Perspective the organization determines how it will achieve the value proposition for its customers and the productivity improvements to reach its financial objectives in order to satisfy its shareholders. This perspective measures the business processes that have the greatest impact on customer satisfaction. It measures factors like quality and employee skills. Here, companies should identify and measure their core competencies and technologies critical to ensuring market leadership (Magu, 2013).Measures that can represent this perspective are inventory turnover, delivery, productivity, cycle time, and research and development expenses (Kimaro, 2013).

Internal business process perspective strives to identify processes that are most critical for satisfying customers and shareholders (Nzuve \& Nyaega, 2013). Gitachu (2012) proposes that a company must pursue one of the three customer value disciplines in order to maximize effectiveness in customer satisfaction. This includes the Operational excellence, product leadership and customer intimacy (Kariuki, 2012). The operational excellence is the provision of the reliable products at competitive prices while ensuring ease in their availability and accessibility with minimal difficulty to customers (Kiragu, 2012). The product leadership is the provision of products that continually redefine the state of the art and innovation and Customer intimacy; selling the customer a total solution to their needs (Momanyi, 2012). Thus any organization must identify its internal business processes that will drive it to achieve its objectives.

According to Gitachu (2012), parameter metrics in the business process perspective, should reflect and directly support the company's customer value discipline as stipulated in its strategy. For example, a company that pursues a product leadership strategy should focus on creativity and innovation. The lack of these innovative and creative measures characterizes a weak link between the stated value discipline and the internal operational processes of the company that execute the strategy (Thuo, 2012). Managers need to focus on those critical internal operations that enable them to satisfy customer needs. The Scorecard should stem from the business processes that have the greatest impact on customer satisfaction such as factors that affect cycle time, quality, employee skills, and productivity (Kinya, 2012). Thuo (2012) indicate that a company's ability to innovate, create, improve and learn ties directly to the company's capacity and value, through the ability to launch new products, create more value for customers and improve operating efficiencies continually. Thus a company should have the ability to penetrate new markets, increase market share and increase revenues and margin resulting in growth and increase in shareholder value (Wanyutu, 2014). According to Kariuki (2012) internal processes perspective controls the ability of an organization to develop new productive processes and enhance its production technology in line with the market trends. The most used indices are the time to introduce and market a new product and the number of new processes implemented as they have a direct impact on customer satisfaction (Nyaega, 2012). 


\section{Influence of learning and growth perspective of the balance scorecard on efficiency}

The learning and growth perspective identifies the needed infrastructure to support the other three perspectives by measuring the organization's ability to innovate, improve, and learn (Kimaro, 2013). Nyaega (2012) argues that measures of the Learning and Growth Perspective are the enablers of the other perspectives and represent the foundation of the BSC. According to Kebu (2015), continual improvements and the ability to learn and introduce new products and services are the precondition to survive, expand in the global marketplace, and increase the company's value. Knowledge, employee skills and satisfaction, the availability of information and adequate tools are frequently the source of growth and therefore the most common measures of this perspective (Otieno, 2010).

Learning and growth perspective is directly linked to a company's identified value discipline and involves a company's ability to continuously learn, innovate, create and improve its competitive advantage (Nyaega, 2012). A strong internal human resource characterized by knowledge, skills and expertise, information communication and organizational capabilities are the ingredients of learning and growth (Elesani, 2012). Intangible assets are the ultimate end resources of stable value creation. They describe the goals of growth and learning, the quality of persons' skills and knowledge integration, advanced technologies and other related supportive factors to the organization's strategy (Gitachu, 2012). The advancement of growth and learning measures are the leading indices for exemplary internal processes, customers' satisfaction and financial performance (Wanyutu, 2014).

Human resource management has a significant impact on organizational performance and can enhance its competitive advantage in the market (Okeyo, 2014). Effective human resource management is especially important in the service industry because employees have direct one on one contact with customers (Magu, 2013). Some literature claims that customer satisfaction is also influenced by employee satisfaction, morale and staff turnover rate and operation efficiency, which in turn affects the financial performance and impacts on the overall organizational performance (Wekesa, 2015).

\section{Objective of the Study}

The specific objectives of the study include;

(i) To examine how the financial perspective of the balance scorecard has influenced efficiency at the KEBS.

(ii) To determine how the customer perspective of the balance scorecard has influenced efficiency at KEBS.

(iii) To find out the influence of the internal business process perspective of the balance scorecard on efficiency at the KEBS.

(iv) To determine the influence of learning and growth perspective of the balance scorecard on the efficiency at KEBS.

The research hypotheses include;

\section{Research Hypotheses}

(i) $\mathbf{H}_{01}$ : There is no significant influence of financial perspective of the balance scorecard on organizational efficiency at KEBS

(ii) $\mathbf{H}_{02}$ : There is no significant influence of customer perspective of the balance scorecard on organizational efficiency at KEBS

(iii) $\mathbf{H}_{03}$ : There is no significant influence of internal business process perspective of balance scorecard on organizational efficiency at KEBS

(iv) $\mathbf{H}_{04}$ : There is no significant influence of learning and growth perspective of balance scorecard on organizational efficiency at KEBS

\section{Methodology}

Cooper \& Schindler (2011) assert that in designing a research instrument, the use of constructs has played an important role in management research. The scholars postulate that constructs are defined as latent variables that cannot be measured directly (Mugenda \& Mugenda, 1999). This study will adopt quantitative research approaches due to ease of data analysis. The descriptive research design will be utilized for the study. The descriptive research design describes the phenomenon as it is on the ground without any manipulation of the variables. The target population of this study was the management staff from KEBS' 15 departments namely: Standards development, Quality assurance and Inspection, Quality processes, Certification body, legal, ICT, Internal audit, Customer communication, National quality institute, Metrology, Testing, Market surveillance, Finance, Human resource and Procurement which consisted of 150 employees. The sample size was calculated using the Yamane (1967) simplified formula as follows;

$\mathrm{n}=\mathrm{N} /\left[1+\mathrm{N}\left(\mathrm{e}^{2}\right)\right]=150 /\left[1+150\left(0.05^{2}\right)\right]=109$ respondents

Where $\mathrm{n}=$ sample size 
$\mathrm{N}=$ Population size $=150$

$\mathrm{e}=$ tolerable error $(5 \%)$ at $95 \%$ confidence level

A sample size of 109 respondents was thus used for the study. The simple random sampling method was used for the purposes of eliminating any bias. The sample size of 109 respondents that were used for this study was calculated using YaroYamane (1967) simplified formula. Therefore, a total of 109 questionnaires were distributed to the respondents and of which 100 questionnaires were returned. This constituted $91.74 \%$ response rate. This response rate was determined to be adequate in the context that it surpassed the $70 \%$ response rate minimum threshold set by Mugenda \& Mugenda (1999). The high response rate was attributed to the constant reminders to the respondents through use of the Short Text Messaging on need to fill the questionnaires, progress in filling the questionnaires, and the collection dates of the questionnaires. A further six questionnaires were not analysed due to incompletely filled questionnaires.

\section{Findings And Discussions}

\section{Effect of Financial Perspective of the Balance Scorecard on Efficiency at KEBS}

The effect of financial perspective on efficiency at KEBS was examined using five metrics; adequate overall budgetary allocation, sufficient departmental budgetary allocation, timely release of funds, efficient resources utilization, and adequate audit mechanisms to ensure efficient utilization of financial resources. The frequencies of the influence of financial perspective of the Balance Scorecard on Efficiency at KEBS were examined as illustrated in Table 1 below. The results for the adequacy of the budgetary resources to KEBS were $10.6 \%, 16.0 \%, 12.8 \%, 34.0 \%$, and $26.6 \%$ of the respondents strongly disagreed, disagreed, were uncertain, agreed and strongly agreed respectively. KEBS have different mandates that require sufficient resources for them to be executed on time and in a cost efficient manner while producing optimum results. The ability of KEBS to have sufficient resources implies that it is able to recruit and retain talented staff, embrace best practices from across the world, obtain cutting edge technology, and continually empower its staff with a view of executing its mandates in an optimal manner. These metrics therefore lead to greater organizational efficiency at KEBS.

In respect to the sufficiency of the departmental budgetary allocation were $10.6 \%, 5.3 \%, 10.6 \%$, $51.1 \%$, and $22.3 \%$ of the respondents choosing strongly disagree, disagree, uncertain, agree and strongly agree respectively. The results showed that $73.4 \%$ of the respondents agree and strongly agree that their departments receive sufficient funds to execute their work. The sufficiency of the departmental budget allocation is of critical concern to the KEBS departments in order for them to be able to execute their mandates at the departmental level and hence achieve the organizational efficiency. The ability for each department to play its roles effectively in the value chain leads to KEBS ability to execute its mandates faster and with little resources wastage leading to organizational efficiency hence achieve customer satisfaction. In this context, Onyango (2014) notes that since profitability or market share is not the primary objective for most governmental organizations, the structural framework of the BSC can be rearranged to place satisfaction of customers of these organizations or the goodwill of the constituents at the top of the hierarchy.

On the other hand, the results for the timely release of funds were $0.0 \%, 18.1 \%, 12.8 \%, 46.8 \%$, and $22.3 \%$ of the respondents choosing strongly disagree, disagree, uncertain, agree and strongly agree respectively. The results showed that on average a cumulative percentage of $69.1 \%$ of the respondents agreed and strongly agreed that the funds were released on time at KEBS. The release of funds in a timely manner implies that KEBS is able to plan on its organizational activities such as field works and audits whenever they are is need to and within the required scope without any delays due to budget constraints. This is key element aiding in organizational efficiency at KEBS.

The results for efficient resources utilization were $10.6 \%, 12.8 \%, 12.8 \%, 41.5 \%$, and $22.3 \%$ of the respondents choosing strongly disagree, disagree, uncertain, agree and strongly agree respectively. Finally, the results for results for the adequacy of audit mechanisms to ensure efficient utilization of financial resources to KEBS were $0.0 \%, 12.8 \%, 10.6 \%, 54.3 \%$, and $22.3 \%$ of the respondents choosing strongly disagree, disagree, uncertain, agree and strongly agree respectively. The need for efficient resources utilization as well as adequacy of audit mechanisms to ensure efficiency utilization of financial resources is critical aspects of organizational efficiency at KEBS. This is in line with the views of Gitonga (2014) who suggested that cost management is a management accounting technique for planning and control in any organization's operation and production costs which is one of the management control systems (MCS) for improved firm success. Therefore it is critical to ensure that KEBS utilizes the funds to execute its mandates in an efficient manner which implies no wastage or corruption related activities.

Table 1; Frequency of Effect of Financial Perspective

\begin{tabular}{|l|l|l|l|l|l|l|}
\hline & SD & D & U & A & SA & TOTAL \\
\hline $\begin{array}{l}\text { KEBS receives adequate and sufficient budgetary allocation } \\
\text { to undertake its mandates }\end{array}$ & $10.6 \%$ & $16.0 \%$ & $12.8 \%$ & $34.0 \%$ & $26.6 \%$ & $100 \%$ \\
\hline
\end{tabular}




\begin{tabular}{|l|l|l|l|l|l|l|}
\hline $\begin{array}{l}\text { KEBS allocates sufficient budgetary allocations to diverse } \\
\text { departments to enable achievement of departmental } \\
\text { objectives }\end{array}$ & $10.6 \%$ & $5.3 \%$ & $10.6 \%$ & $51.1 \%$ & $22.3 \%$ & $100 \%$ \\
\hline $\begin{array}{l}\text { KEBS releases the required funds to undertake diverse } \\
\text { activities (expenditures) in a timely manner }\end{array}$ & $0.0 \%$ & $18.1 \%$ & $12.8 \%$ & $46.8 \%$ & $22.3 \%$ & $100 \%$ \\
\hline $\begin{array}{l}\text { My department at KEBS embraces diverse techniques to } \\
\text { ensure efficient utilization of financial resources }\end{array}$ & $10.6 \%$ & $12.8 \%$ & $12.8 \%$ & $41.5 \%$ & $22.3 \%$ & $100 \%$ \\
\hline $\begin{array}{l}\text { My department has sufficient audit mechanisms to enable } \\
\text { efficient utilization of financial resources }\end{array}$ & $0.0 \%$ & $12.8 \%$ & $10.6 \%$ & $54.3 \%$ & $22.3 \%$ & $100 \%$ \\
\hline
\end{tabular}

\section{Influence of Customer Perspective of the Balance Scorecard on Efficiency at KEBS}

The effect of customer perspective on efficiency at KEBs was examined using five metrics; destruction of counterfeit products, best practices to address arising issues, sufficient business inspection tours to ensure compliance with standards, development of new products, and adherence to set timelines in service delivery. The frequencies of the influence of customer perspective on Efficiency at KEBS were examined as illustrated in Table 2 below The results for destruction of counterfeit products were 5.3\%, 25.5\%, 19.1\%, 31.9\%, and $18.1 \%$ of the respondents choosing strongly disagree, disagree, uncertain, agree and strongly agree respectively. The core mandate of KEBS is ensuring compliance with diverse standards in products and services within the country. The ability therefore to destroy the counterfeit goods is of critical importance to diverse stakeholders and an indication of the organization's ability to execute its mandate efficiently.

The results for the best practices to addressing arising issues were $10.6 \%, 9.6 \%, 19.1 \%, 46.8 \%$ and $13.8 \%$ of the respondents choosing strongly disagree, disagree, uncertain, agree and strongly agree respectively. This is in line with the literature review of the customer perspective. Gitachu (2012) suggests that management should analyse how the customers view the company by measuring lead times, quality, performance and service, and costs. Management should also determine what the company must excel in. This may include the operation and production processes and competencies that are most critical such as cycle time, quality, employee skills, and productivity (Thuo, 2012). The company must also analyse the ability of the company to enhance its performance in ensuring customer satisfaction through launch of new customized and quality products, continuous improvements, creation of value and improve operating efficiencies (Wanyutu, 2014). The embracing of the best practices in its operations implies that KEBS is able to perform efficiently and at par with its counterparts across the world.

In respect of sufficient business inspection tours to ensure compliance with standards, the results were $0.0 \%, 23.4 \%, 10.6 \%, 31.9 \%$, and $34.0 \%$ of the respondents choosing strongly disagree, disagree, uncertain, agree and strongly agree respectively. These results indicate that a cumulative percentage of $65.9 \%$ of the respondents agreed and strongly agreed that the KEBS was undertaking sufficient business inspection tours to ensure compliance with standards. The ability to enforce compliance with the required standards is a critical performance indicator for KEBS. Therefore, sufficiency of the business inspection tours is key in enforcing these compliance and hence organizational efficiency at KEBS.

The results for development of new products were $5.3 \%, 7.4 \%, 18.1 \%, 51.1 \%$, and $18.1 \%$ of the respondents choosing strongly disagree, disagree, uncertain, agree and strongly agree respectively. The new products development implies that KEBS is responding to the changes in their operating environment and hence continually embracing best practices. This would lead to high levels of organizational efficiency at the institution.

Finally, the responses for adherence to set timelines in service delivery were $5.3 \%, 16.0 \%, 5.3 \%$, $57.4 \%$, and $16.0 \%$ of the respondents choosing strongly disagree, disagree, uncertain, agree and strongly agree respectively. The achievement of the set timelines for the service delivery is a key component of customer satisfaction in any organization. This is in line with the service charters that government introduced in all its organizations to drive the results based management initiatives.

Table 2; Frequency Distribution of Customer Perspective

\begin{tabular}{|l|l|l|l|l|l|l|}
\hline & SD & D & U & A & SA & TOTAL \\
\hline $\begin{array}{l}\text { KEBS has always managed to destroy counterfeit } \\
\text { products within the Kenyan market }\end{array}$ & $5.3 \%$ & $25.5 \%$ & $19.1 \%$ & $31.9 \%$ & $18.1 \%$ & $100 \%$ \\
\hline $\begin{array}{l}\text { KEBS has managed to develop standards in line } \\
\text { with best practices to address arising issues in the } \\
\text { market }\end{array}$ & $10.6 \%$ & $9.6 \%$ & $19.1 \%$ & $46.8 \%$ & $13.8 \%$ & $100 \%$ \\
\hline $\begin{array}{l}\text { KEBS has managed to undertake sufficient business } \\
\text { inspection tours to ensure compliance with standards }\end{array}$ & $0.0 \%$ & $23.4 \%$ & $10.6 \%$ & $31.9 \%$ & $34.0 \%$ & $100 \%$ \\
\hline $\begin{array}{l}\text { KEBS has assisted in development of new products } \\
\text { in the market }\end{array}$ & $5.3 \%$ & $7.4 \%$ & $18.1 \%$ & $51.1 \%$ & $18.1 \%$ & $100 \%$ \\
\hline $\begin{array}{l}\text { My department always adheres to the set timelines } \\
\text { in service delivery to the customers }\end{array}$ & $5.3 \%$ & $16.0 \%$ & $5.3 \%$ & $57.4 \%$ & $16.0 \%$ & $100 \%$ \\
\hline
\end{tabular}


Influence of the Internal Business Process Perspective of the Balance Scorecard on Efficiency at theKEBS

The influence of the internal business process perspective of BSC on efficiency at KEBs was examined using five metrics; conduction of needs assessment on priority areas, measurement and monitoring of achievement of departmental objectives, use of employee performance appraisal to drive efficiency, embracement of best practices in roles execution, and undertaking of benchmarking activities. The frequency distribution results of internal business process perspective were illustrated in Table 3 below. The results for conduction of needs assessment on priority areas were $0.0 \%, 7.4 \%, 0.0 \%, 70.2 \%$, and $22.3 \%$ of the respondents choosing strongly disagree, disagree, uncertain, agree, and strongly agree respectively. The ability for KEBS to undertake the needs assessment is critical for the organization to continually satisfy its customers and meets its objectives in an efficient manner. In this context, Nathan (2015), in the Internal Process Perspective the organization determines how it will achieve the value proposition for its customers and the productivity improvements to reach its financial objectives in order to satisfy its shareholders.

The results for the measurement and monitoring of achievement of departmental objectives were $0.0 \%$, $0.0 \%, 0.0 \%, 70.2 \%$, and $29.8 \%$ of the respondents choosing strongly disagree, disagree, uncertain, agree, and strongly agree respectively. The result shows that none of the respondents disagreed or strongly disagreed with the fact that there are measurement and monitoring of achievement of departmental objectives. The measurement and monitoring of the achievement of the departmental objectives is critical to the organizational efficiency at KEBS. This context is consistent with the views of Magu (2013) and Kimaro (2013). They argue that the Internal Business Process Perspective measures the business processes that have the greatest impact on customer satisfaction. It measures factors like quality and employee skills. Here, companies should identify and measure their core competencies and technologies critical to ensuring market leadership (Magu, 2013).Measures that can represent this perspective are inventory turnover, delivery, productivity, cycle time, and research and development expenses (Kimaro, 2013).

On the other hand, the results for the use of employee performance appraisal to drive efficiency were $5.3 \%, 18.1 \%, 5.3 \%, 41.5 \%$, and $29.8 \%$ of the respondents choosing strongly disagree, disagree, uncertain, agree, and strongly agree respectively. Performance appraisal is a key item in ensuring that employees are executing their roles within the required timelines and within the required standards. These are then key in the organization achieving its lead times and producing items that are of quality nature.

The results for the embracement of best practices in roles execution were $0.0 \%, 5.3 \%, 18.1 \%, 54.3 \%$, and $22.3 \%$ of the respondents choosing strongly disagree, disagree, uncertain, agree, and strongly agree respectively. The best practices are key in the achievement of excellence in diverse aspects of the organizational process, services and products. This includes the Operational excellence, product leadership and customer intimacy (Kariuki, 2012). The operational excellence is the provision of the reliable products at competitive prices while ensuring ease in their availability and accessibility with minimal difficulty to customers (Kiragu, 2012). The product leadership is the provision of products that continually redefine the state of the art and innovation and Customer intimacy; selling the customer a total solution to their needs (Momanyi, 2012). Thus any organization must identify its internal business processes that will drive it to achieve its objectives. Finally, the results for the undertaking of benchmarking activities were $12.8 \%, 9.6 \%, 11.7 \%, 38.3 \%$, and $27.7 \%$ of the respondents choosing strongly disagree, disagree, uncertain, agree, and strongly agree respectively. The benchmarking ensures that the organizations are able to adopt best practices from across the world.

Table 3; Frequency Distribution of Internal Business Process Perspective

\begin{tabular}{|c|c|c|c|c|c|c|}
\hline & SD & $\mathbf{D}$ & $\mathbf{U}$ & $\mathbf{A}$ & SA & TOTAL \\
\hline $\begin{array}{l}\text { KEBS conducts a needs assessment of priority areas on regularly } \\
\text { basis }\end{array}$ & $0.0 \%$ & $7.4 \%$ & $0.0 \%$ & $70.2 \%$ & $22.3 \%$ & $100 \%$ \\
\hline $\begin{array}{l}\text { KEBS measures and monitors its achievement of departmental } \\
\text { objectives on a regular basis }\end{array}$ & $0.0 \%$ & $0.0 \%$ & $0.0 \%$ & $70.2 \%$ & $29.8 \%$ & $100 \%$ \\
\hline $\begin{array}{l}\text { KEBS uses employee performance appraisal to drive organizational } \\
\text { efficiency }\end{array}$ & $5.3 \%$ & $18.1 \%$ & $5.3 \%$ & $41.5 \%$ & $29.8 \%$ & $100 \%$ \\
\hline My department embraces best practices in the execution of its roles & $0.0 \%$ & $5.3 \%$ & $18.1 \%$ & $54.3 \%$ & $22.3 \%$ & $100 \%$ \\
\hline $\begin{array}{l}\text { My department undertakes benchmarking activities to ensure that it } \\
\text { achieves its targets }\end{array}$ & $12.8 \%$ & $9.6 \%$ & $11.7 \%$ & $38.3 \%$ & $27.7 \%$ & $100 \%$ \\
\hline
\end{tabular}

\section{Influence of Learning and Growth Perspective of the Balance Scorecard on the Efficiency at KEBS}

The influence of Learning and Growth Perspective of BSC on efficiency at KEBs was examined using five metrics; training of staff on arising challenges, allocation of mentors and coaches for talent identification, scouting and employment of talented staff, participation in conferences and seminars, and undertaking of defined in house courses. The frequency distribution of learning and growth perspective was illustrated through Table 4 below. The results for the training of staff on arising challenges were $4.3 \%, 14.9 \%, 8.5 \%, 40.4 \%$, and $31.9 \%$ of the respondents choosing strongly disagree, disagree, uncertain, agree, and strongly agree respectively. 
For KEBS to perform in an efficient manner, it needs to keep on empowering its employees through continuous training on arising issues. The inability to undertake this crucial exercise would imply that the organization remains static with little development. The results for allocation of mentors and coaches for talent identification were $5.3 \%, 12.8 \%, 36.2 \%, 37.2 \%$, and $8.5 \%$ of the respondents choosing strongly disagree, disagree, uncertain, agree, and strongly agree respectively. These results indicate that a cumulative percentage of $45.7 \%$ of the respondents agreed and strongly agreed that there were allocation of mentors and coaches for talent identification. This is critical for the organization to nurture talented staff with deeper insights and innovation on the workings of KEBS hence improving on the organizational efficiency. On the other hand, the results for scouting and employment of talented staff were $0 \%, 0 \%, 10.6 \%, 54.3 \%$, and $35.1 \%$ of the respondents choosing strongly disagree, disagree, uncertain, agree, and strongly agree respectively. The results for participation in conferences and seminars were $0 \%, 0 \%, 10.6 \%, 54.3 \%$, and $35.1 \%$ of the respondents choosing strongly disagree, disagree, uncertain, agree, and strongly agree respectively. The participation in conferences and seminars ensures that the staffs are equipped with new and best practices that can be used for the improvement of the organizational efficiency at KEBS. Finally, the results for the undertaking of defined in house courses was $5.3 \%$., $7.4 \%, 16.0 \%, 36.2 \%$, and $35.1 \%$ of the respondents choosing strongly disagree, disagree, uncertain, agree, and strongly agree respectively. The setting of certain minimum courses for given roles ensures that the staff assuming new roles are able to be brought at par with their colleagues hence ensuring that they don't compromise quality and lead time in service delivery.

Table 4; Frequency Distribution of Learning and Growth Perspective

\begin{tabular}{|c|c|c|c|c|c|c|}
\hline & SD & D & $\mathbf{U}$ & $\mathbf{A}$ & $\mathbf{S A}$ & TOTAL \\
\hline $\begin{array}{l}\text { My department occasionally trains staff on arising challenges } \\
\text { in work execution }\end{array}$ & $4.3 \%$ & $14.9 \%$ & $8.5 \%$ & $40.4 \%$ & $31.9 \%$ & $100 \%$ \\
\hline $\begin{array}{l}\text { My departments allocates mentors and coaches to identified } \\
\text { talents within the department }\end{array}$ & $5.3 \%$ & $12.8 \%$ & $36.2 \%$ & $37.2 \%$ & $8.5 \%$ & $100 \%$ \\
\hline $\begin{array}{l}\text { My department scouts and employs talented staff from outside } \\
\text { the organization to make it competitive }\end{array}$ & $21.3 \%$ & $5.3 \%$ & $21.3 \%$ & $46.8 \%$ & $5.3 \%$ & $100 \%$ \\
\hline $\begin{array}{l}\text { My department occasionally participates on conferences and } \\
\text { seminars in order to improve on its skills }\end{array}$ & $0 \%$ & $0 \%$ & $10.6 \%$ & $54.3 \%$ & $35.1 \%$ & $100 \%$ \\
\hline $\begin{array}{l}\text { Each of the role job has a defined in-house courses that one } \\
\text { must have undertaken }\end{array}$ & $5.3 \%$ & $7.4 \%$ & $16.0 \%$ & $36.2 \%$ & $35.1 \%$ & $100 \%$ \\
\hline
\end{tabular}

\section{Organizational Efficiency}

The organizational efficiency was examined using five metrics; timely certification of products, achievement of firms audited targets, sufficiency of sensitization workshops and seminars, and issuance of sufficient numbers of ISO certifications. The frequency distribution results for organizational efficiency are illustrated in Table 5 below. The results for timely certification of products were $0.0 \%, 23.4 \%, 5.3 \%, 47.9 \%$, and $23.4 \%$ of the respondents choosing strongly disagree, disagree, uncertain, agree, and strongly agree respectively. The timeliness of the service delivery is key as it shows that KEBS is able to undertake its roles within a set timeline. The results for achievement of firms audited targets include $0.0 \%, 5.3 \%, 16.0 \%, 62.8 \%$, and $16.0 \%$ of the respondents choosing strongly disagree, disagree, uncertain, agree, and strongly agree respectively. The ability of KEBS to achieve the target number of firms for compliance levels is critical measurement of its organizational efficiency. The results for sufficiency of sensitization workshops and seminars were $0.0 \%, 7.4 \%, 21.3 \%, 39.4 \%$, and $31.9 \%$ of the respondents choosing strongly disagree, disagree, uncertain, agree, and strongly agree respectively. The sensitization campaigns ensure that ensures that there is greater compliance hence enhancing the organizational efficiency at KEBS. Finally, the results for the issuance of sufficient numbers of ISO certifications were $0.0 \%, 0.0 \%, 10.6 \%, 64.9 \%$, and $24.5 \%$ of the respondents choosing strongly disagree, disagree, uncertain, agree, and strongly agree respectively.

Table 5; Frequency Distribution of Organizational Efficiency

\begin{tabular}{|l|l|l|l|l|l|l|}
\hline \multicolumn{1}{|l|}{ SD } & D & U & A & SA & TOTAL \\
\hline $\begin{array}{l}\text { KEBS has certified all the products meeting the required } \\
\text { standards in a timely manner }\end{array}$ & $0.0 \%$ & $23.4 \%$ & $5.3 \%$ & $47.9 \%$ & $23.4 \%$ & $100 \%$ \\
\hline $\begin{array}{l}\text { KEBS achieves its targets on the firms that it needs to audit in } \\
\text { a given period }\end{array}$ & $0.0 \%$ & $5.3 \%$ & $16.0 \%$ & $62.8 \%$ & $16.0 \%$ & $100 \%$ \\
\hline $\begin{array}{l}\text { KEBS has undertaken sufficient sensitization workshops and } \\
\text { seminars }\end{array}$ & $0.0 \%$ & $7.4 \%$ & $21.3 \%$ & $39.4 \%$ & $31.9 \%$ & $100 \%$ \\
\hline $\begin{array}{l}\text { KEBS Manages to issue sufficient numbers of ISO } \\
\text { Certifications in a given year }\end{array}$ & $0.0 \%$ & $0.0 \%$ & $10.6 \%$ & $64.9 \%$ & $24.5 \%$ & $100 \%$ \\
\hline
\end{tabular}

\section{Inferential Statistics}

The inferential statistics were examined using the correlation analysis and the multiple linear regressions. The correlation analysis was undertaken of each individual independent variable against the dependent variable. 


\section{Influence of Financial Perspective on organizational efficiency at KEBS}

The linear correlation was used to test the hypotheses of the financial perspective which is illustrated in Table 6 below. The $p$ value was compared with the significance level and if the $p$ value was less than the 0.05 significance level then the null hypotheses was rejected. On the other hand, if the $\mathrm{p}$ value was greater than the 0.05 significance level then the null hypotheses was accepted.

$\mathrm{H}_{01}$ : There is no significant influence of financial perspective of the balance scorecard on efficiency at KEBS.

$\mathrm{H}_{\mathrm{Al}}$ : There is significant influence of financial perspective of the balance scorecard on efficiency at KEBS.

The results in table 4.16 indicates that $r=0.571$ and $\mathrm{p}<0.05$ and thus we reject the null hypothesis and conclude that there is a significant influence of the financial perspective of the BSC on efficiency at KEBS. The financial perspective aspect of the BSC is critical at KEBS as the correlation results indicate. This is in line with the literature review. According to Kinya (2012), measures in the Financial Perspective indicate whether the implementation of the company strategy and its execution are contributing to the improvement of the bottomline results. Focusing resources, energy, and capabilities on customer satisfaction, quality, knowledge, and other factors in the other perspectives without incorporating indicators showing the financial returns of an organization may produce little added value (Thuo, 2012). According to Gitachu (2012), the Financial Perspective focuses on measures which have the goal of enhancing shareholder value. The most commonly used measures are derived from the objectives of revenue growth and productivity, such as return on equity, return on investment, revenue, gross margin, and other indicators (Nyaega, 2012).

Table 6; Correlation Analysis of Financial Perspective

\begin{tabular}{|l|l|l|}
\hline \multicolumn{2}{|c|}{ Financial Perspective } & $\begin{array}{l}\text { Organizational } \\
\text { efficiency }\end{array}$ \\
\cline { 2 - 3 } & Pearson Correlation & $.571^{* *}$ \\
\cline { 2 - 3 } & Sig. (2-tailed) & .000 \\
\cline { 2 - 3 } & $\mathrm{N}$ & 94 \\
\hline
\end{tabular}

Significance Level 0.05

\section{Influence of Customer Focus Perspective on Efficiency at KEBS}

The linear correlation was used to test the hypotheses of the customer perspective as illustrated in Table 7 below. The $p$ value was compared with the significance level and if the $p$ value was less than the 0.05 significance level then the null hypotheses was rejected. On the other hand, if the $\mathrm{p}$ value was greater than the 0.05 significance level then the null hypotheses was accepted.

$\mathrm{H}_{02}$ : There is no significant influence of customer perspective of the balance scorecard on efficiency at KEBS $\mathrm{H}_{02}$ : There is significant influence of customer perspective of the balance scorecard on efficiency at KEBS

The relationship was found to be positive and statistically significant since $r=0.601, p<0.05$. Since $p$ value is less than 0.05 then the null hypothesis $\mathrm{H}_{02}$ was rejected and concluded that there is a significant influence of customer perspective of the balance scorecard on efficiency at KEBS. Customer perspective aims at individualizing objectives and measures to control the level of customer satisfaction through numerous rating indices, like the rate of acquisition of new customers, the market share of the chosen segment and customer retention (Kinya, 2012). If customers are not satisfied, they will find other suppliers that are more sensitive to their needs and desires (Thuo, 2012). Poor performance in customer focus is a leading indicator of future decline in growth and sustainability of the organization, even though the current financial picture may look good as it will eventually lead to decrease in market share as the customers move to where they feel they will get better services (Wanyutu, 2014).

Table 7; Correlation Analysis of Customer Perspective

\begin{tabular}{|l|l|l|}
\hline \multirow{2}{*}{$\begin{array}{l}\text { Customer } \\
\text { Perspective }\end{array}$} & Pearson Correlation & $\begin{array}{l}\text { Organizational } \\
\text { Efficiency }\end{array}$ \\
\cline { 2 - 3 } & Sig. (2-tailed) & $.601^{* *}$ \\
\cline { 2 - 3 } & $\mathrm{N}$ & .000 \\
\hline
\end{tabular}

Significance Level 0.05

\section{Influence of Internal Business Process Perspective on Efficiency at KEBS}

The linear correlation was used to test the hypotheses of the internal business process perspective as illustrated in Table 8 below. The $\mathrm{p}$ value was compared with the significance level and if the $\mathrm{p}$ value was less than the 0.05 significance level then the null hypotheses was rejected. On the other hand, if the $p$ value was greater than the 0.05 significance level then the null hypotheses was accepted.

$\mathrm{H}_{03}$ : There is no significant influence of internal business process perspective of balance scorecard on efficiency at KEBS 
$\mathrm{H}_{\mathrm{A} 3}$ : There is significant influence of internal business process perspective of balance scorecard on efficiency at KEBS

The results in table 8 below indicates that the relationship is positive and statistically significant since $\mathrm{r}=0.647, \mathrm{p}<0.05$. Since $\mathrm{p}$ value is less than 0.05 then the null hypothesis $\mathrm{H}_{03}$ was rejected and concluded that there is a significant influence of internal business process perspective of balance scorecard on efficiency at KEBS. The internal business process perspective is critical in the organizational efficiency in any given organization as it impacts on the customer performance. Great customer performance is the result of processes, decisions, and actions which managers need to focus on in order to satisfy customer needs (Gitachu, 2012). According to Nathan (2015), in the Internal Process Perspective the organization determines how it will achieve the value proposition for its customers and the productivity improvements to reach its financial objectives in order to satisfy its shareholders. This perspective measures the business processes that have the greatest impact on customer satisfaction. It measures factors like quality and employee skills. Here, companies should identify and measure their core competencies and technologies critical to ensuring market leadership (Magu, 2013).Measures that can represent this perspective are inventory turnover, delivery, productivity, cycle time, and research and development expenses (Kimaro, 2013).

Table 8; Correlation Analysis of Internal Business Process Perspective

\begin{tabular}{|l|l|l|}
\hline & & $\begin{array}{l}\text { Organizational } \\
\text { Efficiency }\end{array}$ \\
\hline \multirow{2}{*}{$\begin{array}{l}\text { Internal Business Process } \\
\text { Perspective }\end{array}$} & Pearson Correlation & $.647^{i *}$ \\
\cline { 2 - 3 } & Sig. (2-tailed) & .000 \\
\cline { 2 - 3 } & $\mathrm{N}$ & 94 \\
\hline
\end{tabular}

Significance Level 0.05

\section{Influence of Learning and Growth Perspective on Efficiency at KEBS}

The linear correlation was used to test the hypotheses of the learning and growth perspective as illustrated in Table 9 below. The $p$ value was compared with the significance level and if the $\mathrm{p}$ value was less than the 0.05 significance level then the null hypotheses was rejected. On the other hand, if the $p$ value was greater than the 0.05 significance level then the null hypotheses was accepted.

$\mathrm{H}_{04}$ : There is no significant influence of learning and growth perspective of balance scorecard on efficiency at KEBS

$\mathrm{H}_{\mathrm{A} 4}$ : There is significant influence of learning and growth perspective of balance scorecard on efficiency at KEBS

The relationship as shown in Table 9 was found to be positive and statistically significant since $r=0.704, p<0.05$. Since $p$ value is less than 0.05 then the null hypothesis $\mathrm{H}_{04}$ was rejected and concluded that There is a significant influence of learning and growth perspective of balance scorecard on efficiency at KEBS .The learning and growth perspective identifies the needed infrastructure to support the other three perspectives by measuring the organization's ability to innovate, improve, and learn (Kimaro, 2013). Nyaega (2012) argues that measures of the Learning and Growth Perspective are the enablers of the other perspectives and represent the foundation of the BSC. According to Kebu (2015), continual improvements and the ability to learn and introduce new products and services are the precondition to survive, expand in the global marketplace, and increase the company's value. Knowledge, employee skills and satisfaction, the availability of information and adequate tools are frequently the source of growth and therefore the most common measures of this perspective (Otieno, 2010).

Table 9; Learning and Growth Perspective

\begin{tabular}{|l|l|l|}
\hline \multirow{2}{*}{$\begin{array}{l}\text { Learning and Growth } \\
\text { Perspective }\end{array}$} & $\begin{array}{l}\text { Organizational } \\
\text { Efficiency }\end{array}$ \\
\cline { 2 - 3 } & Pearson Correlation & $.704^{* *}$ \\
\cline { 2 - 3 } & Sig. (2-tailed) & .000 \\
\cline { 2 - 3 } & $\mathrm{N}$ & 94 \\
\hline
\end{tabular}

Significance Level 0.05

\section{Regression Analysis}

To make the conclusion of this study, the researcher utilized the multiple linear regression with a view of explaining the cumulative effects of the independent variables on the dependent variable. The multiple linear regression therefore examined the effects of Learning \& Growth, Customer focus, internal Business Process, and Financial Perspectives of the Balanced Scorecard on the organizational efficiency at KEBS. The multiple linear regression correlation coefficient explains the relationship between the four independent variables and the dependent variable. 
The multiple linear regression correlation coefficient of 0.765 in Table 10 below indicates a strong and positive relationship between the cumulative effect of the four independent variables and the dependent variable. The four independent variables accounted for $56.6 \%$ of the variance in the organizational efficiency at KEBS as indicated by an adjusted $\mathrm{R}$ square of 0.566 in table 10 below. Therefore, $43.4 \%$ of the variance in the organizational efficiency at KEBS is attributed to other variables not within the scope of this study.

Table 10; Model Summary

\begin{tabular}{|l|l|l|l|l|}
\hline Model & R & R Square & Adjusted R Square & Std. Error of the Estimate \\
\hline 1 & $.765^{\text {a }}$ & .585 & .566 & .46574 \\
\hline \multicolumn{2}{|l|}{$\begin{array}{l}\text { a. Predictors: (Constant), Learning \& Growth Perspective, Customer Performance, internal } \\
\text { Business Process Perspective, Financial Performance }\end{array}$}
\end{tabular}

The ANOVA table results as illustrated in Table 11 and more specifically the F-ratio was used in testing the ability of the independent variables to predict the dependent variables. The results show that the independent variables statistically significantly predict the dependent variable, $\mathrm{F}(4,89)=31.3192, \mathrm{p}<.005$ indicating that the regression model is a good fit for the data.

Table 11; ANOVA

\begin{tabular}{|l|l|l|l|l|l|l|}
\hline \multicolumn{2}{|c|}{ Model } & Sum of Squares & Df & Mean Square & F & Sig. \\
\hline \multirow{3}{*}{1} & Regression & 27.174 & 4 & 6.793 & 31.319 & $.000^{\mathrm{b}}$ \\
\cline { 2 - 6 } & Residual & 19.305 & 89 & .217 & & \\
\cline { 2 - 6 } & Total & 46.479 & 93 & & & \\
\hline
\end{tabular}

The unstandardized coefficients in Table 12 below illustrate the variance in organizational efficiency at KEBS as a result of changes in one of the independent variables with the others kept constant. The unstandardized coefficients of financial perspective, Customer perspective, internal Business Process Perspective, and learning \& growth perspective were $-0.116,0.233, .0372$, and 0.465 respectively. This indicates that apart from the financial perspective which has a negative coefficient, the other perspectives have a positive effect on the organizational efficiency at KEBS with the rest of the variables being kept constant. The regression model is illustrated in the equation below;

Organizational Efficiency $=0.353-0.116$ (Financial Perspective) +0.233 (Customer Perspective) +0.372 (internal Business Process Perspective) + 0.465 (Learning \& Growth Perspective).

The organizational efficiency at KEBS would stand at 3.53 if all the independent variables are absent as indicated through a coefficient intercept of 0.353. A unit increase in financial perspective with the other factors kept constant would lead to a decrease in the organizational efficiency by a margin of 0.116 as illustrated through the -0.116 beta coefficient of financial perspective. The financial perspective of the BSC on its own is not sufficient to cause a positive effect on the organizational efficiency at KEBS. The study concludes that financial perspective measurement metrics used may not have been adequate to measure its effect in relation to organizational efficiency. Therefore alternative financial perspective measures such as budgetary compliance, cost reduction, amount of revenue generated, level of utilization of allocated funds, level of development index and debt ratio could be used. Secondly, financial perspective can be seen as a consequence of organizational efficiency rather than it influencing efficiency. This is because organizations strive to improve their learning and growth metrics and internal business processes so as to achieve a competitive advantage and hence attract and keep their customers so as to improve their bottom line as measured using the financial perspective.

A unit increase in customer perspective with the other factors kept constant would lead to an increase in the organizational efficiency by a margin of 0.233 as illustrated through the 0.233 beta coefficient of customer perspective.. A unit increase in internal Business Process Perspective with the other factors kept constant would lead to an increase in organizational efficiency by a margin of 0.372 as illustrated through the 0.372 beta coefficient of internal Business Process Perspective. Finally, a unit increase in Learning \& Growth Perspective with the other factors kept constant would lead to an increase in organizational efficiency by a margin of 0.465 as illustrated through the 0.465 beta coefficient of learning and growth perspective.

Table 12; Multiple Linear Regression Coefficients

\begin{tabular}{|c|c|c|c|c|c|}
\hline \multirow[t]{2}{*}{ Model } & \multicolumn{2}{|c|}{ Unstandardized Coefficients } & \multirow{2}{*}{$\begin{array}{l}\begin{array}{l}\text { Standardized } \\
\text { Coefficients }\end{array} \\
\text { Beta }\end{array}$} & \multirow[t]{2}{*}{$\mathbf{t}$} & \multirow[t]{2}{*}{ Sig. } \\
\hline & Beta & $\begin{array}{l}\text { Std. } \\
\text { Error }\end{array}$ & & & \\
\hline
\end{tabular}




\begin{tabular}{|l|l|l|l|l|l|l|}
\hline \multirow{3}{*}{1} & (Constant) & .353 & .337 & & 1.049 & .297 \\
\cline { 2 - 6 } & Financial Perspective & -.116 & .122 & -.139 & -.951 & .344 \\
\cline { 2 - 7 } & Customer Perspective & .233 & .085 & .245 & 2.755 & .007 \\
\cline { 2 - 7 } & Internal Business Process Perspective & .372 & .137 & .340 & .008 \\
\cline { 2 - 7 } & Learning \& Growth Perspective & .465 & .149 & .422 & .002 \\
\hline \multicolumn{2}{|l|}{ a. Dependent Variable: Organizational Efficiency } \\
\hline
\end{tabular}

\section{Recommendations}

The study recommends that KEBS should focus on the learning and growth perspective of the balanced scorecard as it had the greatest effect on the organizational efficiency at KEBS and also identifies the needed infrastructure to support the other three perspectives. Learning and growth had five metrics that had been examined. KEBS conducting a needs assessment of the priority areas on a regular basis meant that the organization was constantly in touch with the ever dynamic customer preferences, changing best practices and market developments. The study recommends that KEBS should therefore invest on the diversity of means to conduct a needs assessment on diverse areas. The organization should also ensure that it finds the optimum period for undertaking needs assessment of the priority areas. In the context of KEBS measurement and monitoring of the achievement of the departmental objectives on a regular basis, the metric was found critical for the achievement of organizational efficiency. The study recommends that KEBS should concentrate on enhancing its monitoring and evaluation metrics for the achievement of the departmental objectives in order to achieve greater results in organizational efficiency. Performance appraisals track the achievement of the staff targets that have been set on a given performance review period. In this context, the study recommends on the special focus on the learning and development on the performance appraisals at KEBS to enable better performance. The study recommends also that KEBS continuously identify and improve their internal business processes so as to achieve the value proposition of their customers hence meeting their financial objectives.

\section{References}

[1]. Amboga, J. (2009). Adoption of the Balanced Scorecard in Strategy Implementation at the Kenya Wildlife Service. International Journal of Business and Social Sciences, 1(3), 25-27.

[2]. Cooper, R. D., \& Schindler, P. S. (2011). Business Research Methods (11th ed.). New York, United States: McGraw-Hill Publications.

[3]. Elesani, B. (2012). Effectiveness of the Balanced Scorecard in Implementation of Corporate Strategy at CFC Life Assurance Limited. IOSR Journal of Business and Management, 2(3), 65-70.

[4]. Gichana, G. (2012). The Balanced Scorecard as a Strategy Implementation Tool at Orange Telkom Kenya. IOSR Journal of Humanities and Social Science, 2(3), 15-19.

[5]. Gitachu, E. (2012). Challenges of Application of the Balanced Scorecard in Strategy Implementation at the Kenya Electricity Generating Company. Journal of Modern Accounting and Auditing, 1(1), 25-31.

[6]. Gitonga, R. (2014). Balanced Scorecard and Performance of Consolidated Bank of Kenya. Journal of Emerging Issues in Economics, Finance and Banking (JEIEFB), 2(1), 25-36.

[7]. Kagunyi, W. (2014). Application of Balanced Scorecard in Creating Competitive Advantage at Kenya Commercial Bank Limited. International Journal of Innovative Research and Development, 2(3), 45-50.

[8]. Kariuki, C. (2012). Balanced Scorecard as a Strategic Implementation Tool at AAR Kenya Limited. Journal of Business and Management, 2(3), 78-84.

[9]. Kebu, N. (2015). The Balanced Scorecard and Strategy Implementation at the Kenya Electricity Generating Company. Journal of Social Science and Enterprenuership, 2(3), 94-110.

[10]. Kibuchi, M. (2015). The Balanced Scorecard as a Strategic Implementation Tool in National Social Security Fund. Journal of Business Administration and Management Sciences Research, 2(3), 45-54.

[11]. Kimaro, C. (2013). Application of Balanced Scorecard in Strategy Implementation at Deloitte \& Touche East Africa. International Journal of Advanced Research, 2(4), 54-61.

[12]. Kinya, K. (2012). Challenges Of The Balanced Scorecard As A Strategy Implementation Tool In Large Commercial Banks In Kenya. International Business Research, 2(3), 44-45.

[13]. Kiragu, D. N. (2012). A Survey on the Adoption of the Balanced Scorecard by Selected Companies in Kenya. IOSR Journal of Business and Management, 3(4), 29-34.

[14]. Magu, A. (2013). Balanced Scorecard as a Performance Measurement Tool in Insurance Firms in Kenya. Journal of Modern African Studies.

[15]. Momanyi, L. (2012). Balanced Scorecard as a Tool for Strategy Implementation at the Kenya Private Sector Alliance. Journal of Small Business Management, 1(1), 27-33.

[16]. Mugenda, O., \& Mugenda, A. (1999). Research Methods;Quantitative and Qualitative Approaches. Nairobi: Acts Press.

[17]. Mugo, R. (2014). Balanced Scorecard Application in Strategic Management at Flashcom Limited. International Journal of Financial Research, 2(2), 78-85.

[18]. Mureithi, M. (2014). Application of Balanced Score Card as a Strategy Management Process Tool by Kenya Petroleum Refineries Limited. Journal of Business Administration and Management Sciences Research, 2(3), 45-50.

[19]. Nathan, K. (2015). Influence of Balanced Scorecard on Performance of Safaricom Kenya Limited. IOSR Journal of Business and Management, 2(3), 45-49.

[20]. Nyaega, G. (2012). Application of Balanced Scorecard in Performance Measurement at Essar Telecom Kenya Limited. Journal of Management and Business Studies, 1(1), 29-34.

[21]. Nyangayo, N. (2014). Balanced Scorecard and Performance; A Case Study of Cooperative Bank of Kenya. Journal of Business and Management, 2(3), 15-22.

[22]. Nzuve, S. N. M., \& Nyaega, G. (2013). Application of Balanced Scorecard in Performance Measurement At Essar Telecom Kenya Limited. Social Science Research Network (SSRN), 0-9. http://doi.org/10.2139/ssrn.223133.

DOI: $10.9790 / 487 \mathrm{X}-180803112125 \quad$ www.iosrjournals.org 124 | Page 
[23]. Ochieng, E. (2012). Strategic Management Practices By Kenya Bureau Of Standards. International Business Research, 2(3), 25-29.

[24]. Oketch, J. (2015). The Balanced Scorecard as a tool for strategy implementation at Chase Bank Kenya Limited. Journal of Business Administration and Management Sciences Research, 2(3), 4-5.

[25]. Okeyo, P. (2014). Balanced Scorecard in Strategy Implementation at Discovery Learning Alliance of Kenya. International Journal for Management Science and Terchnolog, 2(3), 45-50.

[26]. Omollo, O. (2015). The Balanced Scorecard as Strategy Implemenattion and Performance Measurement Tool at the Parliamentary Service Commission of Kenya. Journal of Business Administration and Management Sciences Research, 2(3), 49-54.

[27]. Onyango, O. (2014). Application of the Balanced Scorecard Framework in Performance Measurement of E-Government Services : Case of Kenya Revenue Authority By. IOSR Journal of Humanities and Social Science, 2(3), 45-54.

[28]. Otieno, G. (2010). The Role of Balanced Scorecard as a Strategic Management Tool in Kenya Commercial Bank. Journal of Modern African Studies, 1(1), 25-32.

[29]. Thuo, E. (2012). The Challenges of Implementation of the Balanced Scorecard Strategy at Safaricom Kenya Limited. International Journal for Management Science and Technology, 2(3), 65-70.

[30]. Wanyutu, J. W. (2014). Application of Balanced Scorecard As a Tool for Strategy Evaluation and Control By Pharmaceutical Manufacturing Firms in Kenya Joan Wairimu Wanyutu a Research Project Submitted in Partial Fulfilment of the Requirement for the Award of the Degree of Master, (November).

[31]. Waruiru, E. (2009). Implementation of the Balanced Scorecard as a Strategic Management Tool at Insurance Company of East Africa. International Journal of Business Performance Management, 1(1), 36-39.

[32]. Wekesa, B. (2015). Evaluation of the application of balanced scorecard in the ministry of foreign affairs and international trade in Kenya. International Business Research, 2(3), 45-50.

[33]. Yamane, Y. (1967). Elementary Sampling Theory. Englewood Cliff, N.J: Prentice Hall. 